\title{
Conceptualizing Temporary Economic Migration to Kuwait
}

\author{
An Analysis of Migrant Churches Based on Migrant Social Location
}

\author{
Stanley John
}

More than 215 million people, or 3 per cent of the world's population, are international migrants living in a country other than the country of their citizenship (World Bank 2011: 18). This article is interested in a specific type of international migrants who travel for the purpose of work and remain in their host countries for a limited period of time. This phenomenon, called temporary economic or labor migration, is characteristic of the system of migration employed in the Gulf Cooperation Council (GCC) countries. ${ }^{1}$ These migrants travel with their faith, establishing churches and religious communities in their host countries. This chapter will seek to understand the diversity and complexity embodied by the temporary economic migrants and the churches they form in Kuwait.

The purpose of this chapter is to conceptualize temporary economic migrants in Kuwait with attention to the key determinants of migrant social location and to discern how these factors shape Christian ministry and missions in the migrant context. The premise of this chapter is that an adequate understanding of the specific type of migrants and migratory system that functions in a particular geographic space is essential for understanding all aspects of migrant life, including the practice of faith. This chapter appropriates the case of temporary economic migration from Kerala, India to Kuwait and the Kerala Pentecostal churches formed by these migrants in the diaspora.

We will begin with a brief introduction to economic migration to Kuwait with a demographic analysis of the ethnic and religious composition of the region. Next we will situate temporary economic migration within the broader migration paradigm. We will discuss current typologies, definitions of diaspora and transnationalism, and engage with Gardner's theory of the two-types of migrants in the Gulf (Gardner 2010: 24). This then will allow us to raise several critical questions that will help to conceptualize temporary economic

1 The Gulf Cooperation Council (GCC) comprises of Bahrain, Kuwait, Oman, Qatar, Saudi Arabia, and United Arab Emirates. 
migrants in Kuwait and the determinants of migrant social location. We will employ this framework to analyze the worship, community and service of the Kerala Pentecostal churches in Kuwait.

Economic migration to Kuwait and the surrounding GCC countries began in the latter half of the twentieth century and continues unabated into the twenty-first century. With the discovery of oil in the 1930s, Kuwait underwent stupendous economic transformation, from a sparsely populated desert into a thriving metropolis. The region soon became the hot spot of economic development and nation building. The major limitation, however, was the lack of a native labor population sufficient to meet the demands of the high rate of economic development (see Kapiszewski 2001: 37). To meet this need, the nations of the Arabian Gulf turned to the labor-rich countries of Southern Asia, Southeast Asia, and other Arab countries in the Middle East and North Africa.

The type of migratory system that characterizes labor migration to Kuwait follows a kafala or sponsorship system that links residency in the country directly to an employment contract with a particular employer who is the kafeel, or sponsor. The system finds its roots in the traditional custom of bonded-labor relationships wherein "workers labored against a debt previously incurred instead of receiving wages" (Human Rights Watch 2010: 36). The migrant's tenure in the country is limited to the duration of the employment contract, which at its conclusion, requires renewal of the contract, a search for a new employer, or the migrant's departure from the country. The multiple facets of the kafala sponsorship system and the context of employment are key determinants of migrant social location as will be demonstrated later in this contribution.

One of the significant changes that took place as a result of the economic boom was the transformation of the Gulf countries into a highly differentiated population between nationals and expatriates. Expatriates now account for the majority of the population in nearly all of the Gulf countries. ${ }^{2}$ In 2008, Qatar had the highest proportion of migrants to the overall population with

2 The two exceptions to the case are Saudi Arabia and Oman with expatriates accounting for 2 per cent and 31.4 per cent respectively in 2008. The expatriate population surpassed the nationals in Bahrain in 2008. Although nationals outnumber expatriates in the overall population in Saudi Arabia, the country receives the highest number of expatriates, 6.6 million, amongst the GCC countries (Baldwin-Edwards 2011: 11). 
87 per cent. United Arab Emirates followed with 81.3 per cent while Kuwait and Bahrain had 67.9 per cent and 51.4 per cent respectively (Baldwin-Edwards 2011: 11). These proportions are accentuated when we consider the labor force in the GCC countries. Migrant workers outnumber nationals in each of the six Gulf countries. They account for 94 per cent of the total labor force in Qatar and 85 per cent in United Arab Emirates and Kuwait. Bahrain and Saudi Arabia follow with 76.7 per cent, and 50.6 per cent respectively (Baldwin-Edwards 2011: 11).

Labor migration altered the ethnic demography of the region. Among the expatriate labor population in Kuwait, non-Arab Asians account for the highest proportion of the labor population with 65.3 per cent followed by Arabs from Middle East and North Africa (MENA) accounting for 30.95 per cent. Migrants from Europe, America and other regions comprise the remaining 4 per cent of the labor population (ILO 2009:19). The top migrant sending countries in 2003 were India $(300,000)$, Egypt $(260,000)$, Bangladesh $(170,000)$, Sri Lanka (170,000), Pakistan (100,000), Syria (100,000), Iran (80,000), Philippines (70,000), and Jordan/Palestine (50,000) (Kapiszewski 2006: 10).

Migration also altered the religious composition of the region. When people migrate, they migrate with their faith. There are no accurate statistics on religious adherents in the census data in Kuwait and the estimate varies significantly depending on the source. The Pew Forum's Global Religious Landscape (Pew Forum 2012) estimates that nearly 74.1 per cent of the population of Kuwait is Muslim, although other reports claim as high as 85 per cent. $^{3}$ Amongst the Kuwaiti nationals, apart from 200 Christian families and a few Baha'i citizens, the population is overwhelmingly Muslim. The majority, about two-thirds, of the Kuwaiti Muslim population, including the royal family, is Sunni, while onethird is Shia. Christians account for 14.3 per cent of the total population (Pew Forum 2011). ${ }^{4}$ These include the Roman Catholic Church $(300,000)$, the Coptic Orthodox Church (70,000), the National Evangelical Church $(40,000)$ and other Christian denominations (30,000). Hindus (300,000), Buddhists (100,000),

3 There are no accurate statistics regarding religion in the Annual Statistics of the Central Statistical Bureau of Kuwait. These figures are the author's approximation based on Pew Forum 2012 Global Religious Landscape project and International Religious Freedom Report (IRFR) 2011 from the Department of State. The World Christian Database (WCD) estimates a significantly lower Christian population of 8.81 per cent and a Muslim population of 86.18 per cent.

4 The IRFR (U.s. Department of State) estimates slightly higher, with 450,000 non-citizen Christians in 2011 or 16 per cent of the country's 2,818,042 population (population estimate World Bank 2011). 
Sikhs (10,000), Baha'i (400) account for 11.6 per cent of the population (U.s. Department of State 2010).

Our picture of the Gulf countries must be informed by the reality of a context that is radically shaped by migration. This demographic analysis of the population of Kuwait reveals an ethnically and religiously diverse context. ${ }^{5}$ However, the presence of diverse ethnic and religious communities must not be mistaken for an integrated society. This principle will prove essential in the next section as we consider the appropriate taxonomy for this group of migrants.

\section{Understanding Temporary Economic Migration}

Temporary economic migration is a facet of the global phenomenon of migration. In this section, we will attempt to situate temporary economic migration within the broader discussion on migration by first engaging the current typologies of migrants and then discussing the phenomenon of migration. Next, we will employ Gardner's two types of migrants to analyze the Kuwaiti context, after which I will propose the key determinants of migrant social location.

Several proposals have been made to conceptualize the different types of migrants. Ted Lewellen, author of the Anthropology of Globalization, identifies nine types of migrants (Lewellen 2002: 130). Those who move within the country usually for employment are internal migrants and are contrasted with international migrants, who, as the term suggests, travel to different countries multiple times and return without making a significant long-term social investment. Immigrants, on the other hand, are those that leave the country of citizenship to live permanently, or for a long term, in another country. Those among the immigrants that continue to maintain contacts in both the country of origin as well as the host country through social, cultural, economic, and political networks are called transnational immigrants. Diaspora, for Lewellen, refers to a group that is dispersed from a homeland to multiple countries. Refugees are those that are dispersed through war or political repression, and by extension, famine, and earthquake. Step-migration refers to a migratory pattern usually from rural to urban; similarly, migratory chain refers to the formation of a complex network so any migrant can follow the network. Circular

5 The diverse ethnic and religious context functions as enclaves and must not be mistaken for integrated society. 
migration refers to routinized migration away from and back to the home community usually for agricultural or labor purposes (Lewellen 2002: 130).

Stephen Castles, professor of sociology at the University of Sydney, outlines the different types of migrations involved in the migrant enterprise. These are highly skilled workers, low-skilled workers, forced migration, family reunion, and a few others such as astronaut phenomenon, return migration, retirement migration, and even posthumous migration (Castles 2002: 1143-1168).

The benefit of these terms lies in their ability to incorporate a broad range of migrants into simple heuristic models. These categories, however, are unable to capture the complexity of the migrants in Kuwait and the other Gulf countries. We begin to move in the right direction with the specific terminology of temporary economic migrants. The International Organization for Migration (Іом) defines temporary economic migrants as "[s]killed, semi-skilled or untrained workers who remain in the receiving country for definite periods as determined in a work contract with an individual worker or a service contract concluded with an enterprise" (IOM 2004: 66; notice that the term temporary is from the perspective of the host country). Christian Dustmann, professor of economics at University College London, specifies four types of temporary migration: circulatory migration, transient migration, contract migration, and return migration (Dustmann 2000: 8). Temporary economic migrants in Kuwait fit the model described by Dustmann; however, it is inadequate to capture the diversity embodied by various types of temporary economic migrants.

Migration to Kuwait is characterized by its transience, rarely transferring into a permanent resident status as assumed by the term immigrant. These migrants are neither immigrants nor visitors. They encompass varying durations from a short-term of two to three years or long-term with up to two or three generations in the diaspora. They represent a highly complex group of people from skilled to non-skilled labor, single migrants to migrants with families, limited labor contracts to extendable contracts, and their tenure in the Gulf is brought to an end either on their own volition, personal or familial commitments, or unanticipated emergency. Thus, we need to expand our current categories to include temporary economic migration.

Another approach to understand migrants is to describe the phenomenon of migration. This approach is essentially descriptive in nature and stems from an anthropological thrust in contrast to sociological categories, such as the ones described above. The two key terms in this set of anthropological literature are diaspora and transnationalism. We will discuss briefly how these terms might be useful in conceptualizing temporary economic migrants in Kuwait. 
There are a variety of definitions associated with the term diaspora. Stéphane Dufoix, in his seminal book Diasporas, observes, "Diaspora has become a term that refers to any phenomenon of dispersion from a place; the organization of an ethnic, national, or religious community in one or more countries; a population spread over more than one territory; the places of dispersion; any nonterritorial space where exchanges take place, and so on" (Dufoix 2008: 2).

The appropriateness of the term for analysis depends on how one might define a diaspora. Dufoix provides an overview of the types of definitions (Dufoix 2008: 21-25). An open definition opts for broad criteria, is inclusive in nature, and less restrictive regarding specific characteristics. ${ }^{6}$ The second type involves categorical definitions. These specify characteristics based on an ideal type and often have the Jewish diaspora as the model. In as much as communities match up to these criteria, they qualify as "true" diaspora. ${ }^{7}$ The third type of definition is what Dufoix calls oxymoronic. These react to the previous definition types' insistence on a point of departure or imagination of homeland, opting instead for a nuanced approach characterized by the multiplicity of factors or "paradoxical identity" such as diversity, heterogeneity, and hybridity. ${ }^{8}$

An open and oxymoronic definition of the term diaspora recognizes that a categorical definition can no longer capture the complexity embodied by diasporic people. Thus, I would argue that the diaspora nomenclature applies to the temporary migrant context in situating the communities in a geographical context other than their place of origin. Furthermore, the multiple identities embodied by the second-generation of temporary migrant workers that are born in the migrant context yet retain citizenship in their parents' place of

6 Dufoix cites Armstrong's definition of diaspora as an example of the open type: "any ethnic collectivity which lacks a territorial base within a given polity, i.e. is a relatively small community throughout all portions of the polity" (Armstrong in Dufoix 2008: 21).

7 William Safran proposes six characteristics in this regard (Safran quoted in Dufoix 2008: 22): (1) dispersion from a "center" to at least two peripheral foreign regions; (2) persistence of a collective memory concerning the homeland; (3) certainty that their acceptance by the host society is impossible; (4) maintenance of an often idealized homeland as a goal of return; (5) belief in a collective duty to engage in the perpetuation, restoration, or security of the country of origin; (6) maintenance of individual or collective relations with the country of origin.

8 Stuart Hall writes, "I use this term metaphorically, not literally: diaspora does not refer us to those scattered tribes whose identity can only be secured in relation to some sacred homeland to which they must at all costs return, even if it means pushing other people into the sea. This is the old, imperializing, hegemonizing form of ethnicity ... the diaspora experience as I intend it here is defined not by essence or purity, but by the recognition of a necessary heterogeneity and diversity; by a conception of 'identity' which lives with and through, not despite, difference; by hybridity" (Hall 1990, quoted in Dufoix 2008: 24). 
origin hints at the type of heterogeneity and hybridity captured in the oxymoronic type of definitions.

Closely related to the notion of diaspora is the phenomenon of transnationalism. Rather than being a term that describes a type of migrant, the term describes a phenomenon of migrant life. It refers to the ways in which migrant communities maintain relations with their countries of origin. Basch, Glick-Schiller, and Blanc-Szanton define transnationalism as, "The process by which immigrants forge and sustain multi-stranded social relations that link together their societies or origin and settlement. We call these processes transnationalism to emphasize that many immigrants today build social fields that cross geographical, cultural, and political borders" (Basch et al. 1994: 7)..$^{9}$ It is often contrasted with popular ideologies of assimilation which presumed that new migrants shed their socio-cultural and linguistic identities for that of the dominant community. Transnational migrants go beyond the confines of the borders of nation-states, establishing social relations and structures that transcend national boundaries.

Temporary economic migrants in Kuwait orient their lives toward the homeland by creating and maintaining transnational ties with their families and friends in the home country. These migrants are shaped by the transient nature of their tenure, the marginality associated with being a migrant worker, and in many cases social discrimination and exclusion. These, among other factors, affirm the transnational ties and the anticipated return homeward.

\section{$4 \quad$ Two Ends of a Spectrum}

Now we turn to an anthropological thick-description to help us understand the complexity embodied by the temporary economic migrants in Kuwait. Andrew Gardner, author of City of Strangers: Gulf Migration and the Indian Community in Bahrain, proposes a two-fold typology of migrants in the Gulf states, namely, transnational proletariat and diasporic elite, based on the bifurcation between the working and professional classes (Gardner 2010: 24). I will employ the two types here as an organizing tool to provide thick-descriptive

9 Lewellen outlines the characteristics of transnational communities (Lewellen 2002: 152): (1) lives lived across borders with a high intensity of ongoing social and economic interaction; (2) made possible as a result of the flexible job market and internationalization of capitalist production and finance; (3) creates a novel type of identity; (4) over time transnationalism becomes independent of its original conditions; (5) transnationals develop new modes of resistance such as diaspora communities and interstate institutions. 
data. However, these ought not to be viewed as dichotomous categories. Rather, these two types occupy the two ends of a spectrum with migrants occupying multiple positions along the continuum.

At one end of the spectrum are transnational proletariats. These are the "Indian foreign laborers in the working class, usually men, alone, with families behind them in India. Their gaze remains fixed on their home in India, and they are transnational in the sense that their social fields, collectively and individually, are spread between two nations but free of neither" (Gardner 2010: 25).

The vast majority of the non-skilled labor force travel to the Gulf states to work in the labor-intensive fields of construction, domestic work, or service industry. In most cases these expatriates are unable to bring their families with them and come for the duration of two years, although the contract can be renewed in some circumstances. The discrimination by the dominant society, the constant threat of deportation, and the 'structural violence' fostered by the kafala sponsorship system affirms the marginal position of these workers in the society (Longva 1997; Gardner 2010; Human Rights Watch 2010).

Even in cases where the circumstances are not as dismal and perhaps even favorable, the lack of opportunities to renew the employment contract and the lack of a system for permanent residency serves as a constant reminder of the brevity of their sojourn in the country. All of these factors foster the imagination of the homeland and the desire to return upon meeting their financial goals of building a house, saving for a child's education, paying for a family member's wedding, or securing sufficient funds to start a small business. For them, maintaining relations with the homeland is never an afterthought - it is their very lifeline and purpose for their journey to the desert. The connection to the homeland is strong and an anticipated outcome upon the conclusion of their employment.

The other end of the spectrum is occupied by the diasporic elites who are the middle and upper classes of the migrant community in the Gulf. Gardner writes, "Their long standing presence in Bahrain, and the disparate ties they maintain with points around the globe, doesn't necessarily make them less transnational than their impoverished countrymen on the island, but it does conform to the basic pattern of a diasporic, if not cosmopolitan, existence" (Gardner 2010: 25).

The highly skilled workers, too, are exposed to similar vulnerabilities of deportation, lack of adequate recourse to justice, and ethnic discrimination. However, their circumstances are far less dismal than for the transnational proletariat. The duration of their employment and length of stay is significantly longer, even extending up to several generations, albeit in a temporary status. 
These are engineers, health care professionals, educators, and businessmen who are typically able to meet the minimum salary requirement to bring their families with them to the diaspora. The duration of their stay varies. Zachariah observes that among the migrants from Kerala, the average length of stay in the Gulf was seven years (Zachariah 2011: 25).

To mitigate these vulnerabilities, the diasporic elites develop strategies and competencies in their diasporic experience. They adopt a simple lifestyle in the Gulf to save up money to remit back home, reminding themselves of the transient nature of life in the Gulf. They invest in real estate, such as rubber plantations, opulent villas, and apartments in the cities far away from the banks of the Middle East. They attempt to restrict interaction with the citizenry outside the arena of employment, developing enclaves and ethnic social networks that provide avenues for social, cultural, and religious identity formation. They also develop what Gardner calls strategic transnationalism, wherein they build transnational networks that span the globe to insure them against the vulnerabilities prevalent in the Gulf states (Gardener 2010: 89).

With reference to Kuwait, we discussed the transnational proletariat and the diasporic elite as two ends of a spectrum in conceptualizing temporary economic migrants. In reality, migrants cannot be neatly categorized into these two categories of workers and elites. They occupy multiple positions along the continuum defined by a set of interrelated and mutually informing factors.

The list of questions below are not intended to be comprehensive, but rather capture the key factors that are determinants of migrant social location along the spectrum of temporary economic migration to Kuwait.

1. Skill level: Does the migrant belong to the highly skilled or low-skilled bracket of employment qualification? The skill level determines the type of employment possibilities, the length of tenure, salary, living conditions, and the overall migrant experience.

2. Tenure: How long is their tenure of employment or how long have they lived in the diaspora? The length of their tenure determines the migrant's social capital and knowledge accrued. The initial contract is limited to two-three years; however, the migrant is able to stay longer if he/she had the opportunity to extend the contract or seek another employer.

3. Employer: Who is the employer or sponsor for the migrant? Comparisons regarding employers can be made on multiple levels: sector of 
employment—whether private or public; company ownership—whether local owner or multi-national corporation; individual employer character-whether benevolent or exploitative. These factors are critical to assess the migrant employment experience.

4. Type of visa: What type of visa do they hold? There are multiple types of visas issued based on type of employment and industry. These vary from driver/domestic worker visa (Article 20), regular work visa (Article 17public sector; Article 18-private sector), and so on. Some migrants opt for a driver visa for the benefit of receiving a driver's permit; however, this might prove restrictive if the individual hopes to change visas in the future.

5. Migration network: How did they arrive in the country? Migrants arrive in the country through either migrant agencies or individual social networks such as family members or friends. Functioning as middlemen in the recruitment process, migrant agencies recruit workers from the home country. With the lack of monitoring mechanisms this process has a high potential for exploitation. Personal migrant networks ensure migrant knowledge competence and provide a social support network.

6. Family reunification: What is the marital status of the migrant and what are the possibilities for the family to join the migrant in the diaspora? The government mandates a minimum salary requirement for migrants in order for them to apply for their family to join them in Kuwait. The government requires a minimum salary of KD $250(\$ 875)$ for a migrant to apply for a visitor visa; the amount increases to KD $400(\$ 1,400)$ if the migrant is seeking a dependent visa for their family.

7. Ethnicity and religion: What is the ethnicity of the migrant and what is his/her religious affiliation? These two aspects are required on every official application. A large-scale survey of low-income migrant workers sponsored by the Qatar National Research Fund, the first of its kind, found Arab Muslim migrants earned slightly more, worked fewer hours, and had fewer roommates in their shared living space than their Hindu South Asian counterparts (Gardner 2013).

Let me briefly illustrate how these dynamics work in the life of the migrant. The social and cultural experience of migrants will be significantly different based on their length of tenure. Most low-skilled workers come on a contract of two to three years, which are sometimes renewed upon extension of the contract. Others, who are highly skilled, are known to stay in the country even up to the second and third generation albeit in a transient state. Closely related to their length of tenure is the nature of labor each group occupies. If their 
tenure in the diaspora is limited to the three to four years stipulated in the initial contract, the migrant's experience is solely shaped by his/her relationship to the initial employer. If the migrant has the opportunity to stay in the country for a longer period, he/she could seek better employment opportunities and thus secure a better experience. Any attempt at conceptualizing migration to the Arabian Gulf must take seriously the transient nature of employment, and the skill-level of the migrants, which are the two key features of temporary economic migration to the Gulf.

The dynamic factors of temporary economic migration outlined above manifest themselves in a migrant religious context. In this section, I will discuss briefly how these realities shape the migrant churches in Kuwait. I will reflect on three aspects of worship, community, and service as manifest among the Kerala Pentecostal migrant churches in this context.

The congregants of the Kerala Pentecostal churches come from the south Indian state of Kerala. Similar churches composed of migrants from various parts of India, Philippines, Egypt, Sri Lanka, Pakistan, Nigeria, among many others, gather for worship on the National Evangelical Church compound in Kuwait City. When the earliest migrants from Kerala began to arrive in the 1950s, they formed the Kuwait Town Malayalee Christian Congregation (КтмСС), which served as an ecumenical gathering of all Christians from Kerala united by the common language of Malayalam. With the growth of the migrant population, churches began to form in keeping with the denominational affiliation in the homeland, whether it be the Church of South of India, Mar Thoma Church, Pentecostal churches, and so on. There are currently at least thirty Pentecostal and neo-Pentecostal churches from Kerala that worship in various parts of Kuwait.

The realities of employment and the vulnerabilities of the migrant context become the recurring points of prayer and intercession by the community. Churches reserve time in the worship service for congregation members to share their testimonies. Prayers for employment, visa complications, and difficulties with employers remain at the forefront amongst these requests. Other requests relate to the needs of the families in the homeland or illness or reports of travel to the homeland. These become the themes of daily prayer amongst the migrant churches.

10 Details of the research on which these observations are based are found in John (2014). 
The church communities are comprised of migrants who arrive in the diaspora for varying lengths of tenure. Those migrants with longer tenure in the diaspora become the senior leaders of the churches, with some having lived in the diaspora for more than thirty years. These senior migrants play a critical role in the administration and oversight of the church, managing the finances and transnational ecclesial ties with the homeland. Veterans in the diaspora serve as hosts to the newer migrants. These come to the church in Kuwait as referred by their churches in the homeland; others come to the church upon the invitation of a friend. The church, then, functions as a place of hospitality to the new migrants. The personal networks become indispensable for new migrants that come to the country without an employment contract. Employing their rich social networks and social capital, the senior members and relatives try to secure employment along with other necessities such as housing, food, cell phone, and driver's license for the new migrant. They function as the local experts and guides for the new migrant in the new diasporic location.

The senior congregants must return to the homeland upon termination of their employment contract or once they reach the mandatory retirement age of 65 years. Not all migrants in the church stay in the diaspora this long; some return to the homeland at the completion of their employment contract lasting three to four years or upon meeting certain financial goals. Others may migrate to countries in North America, Europe or Australia to join other family members. Thus, there is a steady stream of migrants returning to the homeland, but also new migrants coming to the diaspora.

Migrant churches reach out to their fellow migrants in benevolent service of compassion and care. Some migrants experience difficulties with lack of employment, which then places their visas and residency in jeopardy. Some face economic exploitation, with salaries being withheld or, in worst cases, even physical abuse. Not all migrants experience this level of exploitation. The church ministers to these migrants by providing for their needs, lending money, taking up a special collection, and through spiritual and emotional support. The benevolence is not limited to the diaspora context; the majority of their service is oriented toward the homeland. The Kerala Pentecostal churches send remittances to the homeland to help the poor, build homes for widows, support for marriage, education of children of clergy, and support orphanages.

The unique circumstances of temporary economic migration shape the life and practice of the religious communities in the diaspora. These key determinants of migrant social location shape and inform Christian ministry and mission to migrants in Kuwait. 


\section{$7 \quad$ Conclusion}

The purpose of this chapter was to conceptualize temporary economic migration to Kuwait with attention to the key determinants of migrant social location and to discern how these factors shape Christian ministry and missions in the migrant context. We began with an introduction to the migrant context in Kuwait. Through a demographic analysis, the chapter demonstrated that migration has altered the ethnic and religious composition of the region resulting in a diverse context. We can no longer think of the Arabian Gulf as being ethnically homogenous and religiously Islamic.

Our discussion of migration must specify the type of migrants we refer to, whether refugees or asylum seekers or economic migrants, and the migration system at work within that geographical area. In the Arabian Gulf, temporary economic migration facilitated by the kafala sponsorship system is the norm. Hence, we can begin to understand migrants in this context only with attention to unique contextual factors. This article identifies seven determinants of migrant social location; these are: skill level, length of tenure, employer, type of visa, migration network, family reunification, and ethnicity and religion.

We employ the analytical lens developed in the previous section to understand the migrant religious community reflecting on three aspects religious life, namely, worship, community, and service. We noted that the vulnerabilities of migrant life are key themes in the prayers and intercession of the migrants. The senior migrants extend hospitality, drawing on their rich social networks to find housing, employment, and community to the new comers. Lastly, the churches reach out in benevolence to their fellow migrants as well as those in the homeland. The transnational flows of remittance support various benevolence ministries and missions of the church in the homeland.

The chapter demonstrates that in order to understand the migrant churches we must consider the particular geographical context, the migratory phenomenon at work, and the unique social location of the migrants. This sociocultural lens provides us the exegetical tools to understand a congregation of temporary migrant workers and informs how Christian ministry and mission take place in the migrant context. 


\section{Bibliography}

Baldwin-Edwards, Martin (2011). Labour Immigration and Labour Markets in the GCC Countries:National Patterns and Trends. London and Kuwait: LSE Global Governance and Kuwait Programme on Development, Governance and Globalisation in the Gulf States.

Basch, Linda G., Nina Glick-Schiller, and Cristina Szanton Blanc (1994). Nations Unbound: Transnational Projects, Postcolonial Predicaments, and Deterritorialized Nation-States. Langhorne, PA: Gordon and Breach.

Castles, Stephen (2002). "Migration and Community Formation Under Conditions of Globalization." International Migration Review 36, 4: 1143-1168.

Dufoix, Stéphane (2008). Diasporas. Los Angeles: University of California Press.

Dustmann, Christian (2000). Temporary Migration and Economic Assimilation. Discussion Paper No. 186. Bonn, Germany: Institute for the Study of Labor.

Gardner, Andrew (2010). City of Strangers: Gulf Migration and the Indian Community in Bahrain. Ithaca: ILR Press.

Gardner, Andrew (2013). "A Portrait of Low Income Migrants in Qatar: New Data from a Large-Scale Survey." Paper presented at the Center for Gulf Studies at the American University of Kuwait, January 15 in Salmiya, Kuwait.

Human Rights Watch (2010). Walls At Every Turn: Abuse of Migrant Domestic Workers Through Kuwait's Sponsorship System. New York: Human Rights Watch.

Iом (2004). Glossary On Migration. Geneva, Switzerland: International Organization for Migration.

ILO (2009). "International Labour Migration and Employment in the Arab Region." Thematic paper prepared for the Arab Employment Forum, 19-21 October, Beirut.

John, Stanley (2014). Networks, Agents and Mission: Transnational Religion of Kerala Pentecostal Churches in a Context of Temporary Economic Migration to Kuwait. Unpublished doctoral dissertation. Wilmore, KY: Asbury Theological Seminary.

Johnson, Todd M. Ed. World Christian Database. "Kuwait" Leiden/Boston: Brill. http://www.worldchristiandatabase.org (accessed June 2013).

Kapiszewski, Andrzej (2001). Nationals and Expatriates: Population and Labour Dilemmas of the Gulf Cooperation Council States. Reading: Ithaca Press.

Kapiszewski, Andrzej (2006). "Arab Versus Asian Migrant Workers in the G cc Countries." Paper prepared for United Nations Expert Group Meeting on International Migration and Development in the Arab Region. 15-17 May 2006. Beirut, Lebanon.

Lewellen, Ted (2002). The Anthropology of Globalization: Cultural Anthropology Enters the 21st Century. Westport, cт: Bergin and Garvey.

Longva, Anh (1997). Walls Built on Sand: Migration, Exclusion and Society in Kuwait. Boulder, co: Westview Press. 
Pew Forum (2011). Table: Christian Population as Percentages of Total Population by Country. http://www.pewforum.org/2011/12/19/table-christian-population-aspercentages-of-total-population-by-country/ (accessed 1 April 2013).

Pew Forum (2012). Global Religious Landscape. http://features.pewforum.org/grl/ population-percentage.php (accessed 1 April 2013).

The World Bank (2011). Migration and Remittances Factbook 2011. 2nd ed. Washington, DC: The World Bank.

U.s. Department of State (2010). International Religious Freedom Report for 2010. Bureau of Democracy, Human Rights and Labor. http://www.state.gov/j/drl/rls/ irf/2010/148828.htm (accessed 1 April 2013)

U.S. Department of State (2011). International Religious Freedom Report for 2011. Bureau of Democracy, Human Rights and Labor. http://www.state.gov/j/drl/rls/irf/religiousfreedom/index.htm?dlid=192893 (accessed 1 April 2013).

Zachariah, K.C. and S. Irudaya Rajan (2011). "From Kerala to Kerala via the Gulf: Emigration Experiences of Return Emigrants." Working Paper 443. Thiruvananthapuram: Center for Development Studies. 